\title{
3. THE HUMOR AS A FORM OF ARTISTIC EXPRESSION IN EDUCATION
}

\author{
Marius Costel Eși ${ }^{250}$
}

\begin{abstract}
The relevance of the idea of humor at the social level expresses, from our viewpoint, the need to understand, assume and, why not, use it at the level of social communities. Under these conditions, we consider the usefulness and functionality/applicability of such an idea in educational terms, and in particular, at the level of the class of students. Such an idea is the very idea of humor as it is found in the educational dimension. Moreover, our interest is focused upon seeing and to what extent, the idea of humor can be considered to be an art, if we consider stylized / "aestheticized", artistic, expressive criteria. That is why, the assumed purpose of this approach that we have achieved consists in an exhaustive analysis of the idea of humor and, implicitly, of the art of humor in education, as well as of the way in which it manifests and it is recognized at the educational level.
\end{abstract}

Key words: humor as art, educational humor, educational actors, educational pragmatism

\section{Introduction}

The approach we are considering is to implicitly and explicitly analyze a series of features regarding what humor represents in education, how it can be interpreted as a socio-educational indicator and to what extent it can contribute to the performance of an educational/didactic activity. The theme of this research paper reveals an approach through which we follow an exhaustive analysis of what the idea of humor and, implicitly, the art of humor is itself. The topical issue and importance of the research topic reflects the epistemic field expressed in the very empirical investigative approach that we initiated in this paper. Aspects related to the theoretical and practical dimension of the idea of the art of humor in education are discussed.

We consider, in this context, meanings and significance of the idea of humor, the relationship between educational humor - an ethical dimension, but also the relationship between the idea of humor and educational utilitarianism. The key questions of this research can be expressed as follows:

1. "How is humor possible /usable in education?"

2. Is the phrase "humor as an art in education" viable?

Starting from these ideas, we consider that we can take note of what, on the one hand, the idea of humor as a pragmatic expression represents and, on the other hand, as a socio-educational indicator. At the same time, such an approach can represent, in our opinion, a relevant landmark for further research in the field. Therefore, the direction we have established has an educational-pragmatic connotation.

${ }^{250}$ Lecturer PhD., "Stefan cel Mare" University from Suceava, Romania, email: mariusesi@yahoo.com 


\section{Theoretical and practical dimensions for using the idea of humor in education}

In this investigative approach we consider a series of aspects that aim at theoretical and practical dimensions related to the idea of humor and how it can be correlated with the idea of art (the analysis of the conceptual and theoretical relationship that we initiated is of scientific nature).The phrase "art of humor" is not accidental in this title, precisely because it comes to capture the subtlety and elegance of using humor, and the practical value of its use in class and in the educational activity as a whole.

A first argument we consider is that any form of school success can contribute to the idea of educational success. Thus, our distinction ("school success" - "educational success") may suggest a "quasi-perfect" synonymy at the conceptual level, as well as at the theoretical level. However, if we consider the involvement of socio-educational actors involved in school activity, as well as the monitoring of their activities (Cuttance, 1994), then such a distinction is certainly justified especially from a pragmatic perspective.

In other words, we can talk about school success in the conditions in which the responsibility of the actors involved in the educational approach focuses mainly only on the idea of assimilation and the establishment of minimum qualitative evaluation criteria. Or, such criteria, which we should keep in mind at the level of this research, are rather of an ethical, practical / utilitarian and even artistic nature. On the other hand, in our opinion, school success brings with it a qualitative and qualitative surplus regarding the knowledge-type acquisitions, a surplus that can be corroborated precisely to the criteria mentioned above.

A second argument we make is that school performance requires at the level of an exhaustive analysis the consideration of indicators that are more or less scientifically accepted. Such an indicator is given by the idea of humor, an idea that in the literature has various meanings (Martin, Puhlik-Doris, Larsen, Gray \& Weir, 2003; Cann\& Chantal 2014). Under these conditions, we can state that humor, seen as a life experience (Freud, 2002), the recipients of which are both the teacher and the preschooler/pupil (Ianculescu, 2018), in qualitative terms (Biggs, 2003), is and must be part of the educational dimension of the society in which we live (Stieger, Formann, Burger, 2011), contributing to the mental comfort of the actors involved in the school activity.

In fact, according to the opinion of some specialists (Cann, Chantal, 2014) humor itself can bring obvious benefits to those involved (Poweel\& Andresen, 1985), helping to reduce stress (Kavandi\&Kavandi, 2016; McCosker\&. Moran, 2012) and anxiety (Ford, Lappi, O'Connor \&Banos, 2017; Smith, Ascough, Ettinger, \& Nelson, 1971), even depression (Ibarra-Rovillarl\& Kuiper, 2011) and reduce aggression (Weinstein, Hodgins, Ostvik, 2011).Moreover, the elimination of tension in the classroom (among the educational actors participating in the teaching process) can increase the speed of assimilation of the accumulated knowledge (Gorham and Christophel, 1990; Eşi Posteucă, 2019). Therefore, we observe that the use of the idea of humor in education expresses in the opinion of some specialists joy and merriment (Janes\&Olson, 2000), can provide good mood 
(Marcus 2015), can generate emotional relaxation (Rosenheim, E., 1974), can arouse smiles (Bremmer\&Rodenburg, 2006), can determine vital moods (Yovetich, Dale \&Hudak, 1990) and it can strengthen respect (Kher, Molstad\& Donahue, 1999).

In other words, we notice that through humor, the atmosphere in the classroom becomes a relaxing one, the behavior of the educational actors (and even the social ones) involved, can thus be regulated and reorganized (Dent, 2001).The phrase "humor as art in education" therefore refers to a series of valences related to the way in which humor can be seen and understood as art. In addition, such an understanding finds its finality, in our opinion, precisely in the dimension of didactic persuasion / persuasiveness. In fact, through humor, which is perceived as a basic indicator in terms of mental activity (Elias, 1973), the child/preschooler/pupil is "convinced" and stimulated to learn and assimilate new knowledge, thus decreasing the degree of anxiety (Yovetich, Dale, Hudak, 1990).

The applicability of humor in the classroom allows the socio-educational actors to model their own behavior. In this regard, we consider, on the one hand, humor as a specific way of use in teaching (Ziv, 1988; Jeder, 2015), and on the other hand, humor as a generator of new ideas, perceptions in obtaining information and as a specific way of capturing attention (Klein, 1998). Finding humor in educational games (Baid \&Lambert, 2010) only confirms the need of its use at the educational level. Moreover, its pedagogical assumption and perception (Shatz\&Schiavo, 2006) through the scientific substantiation of teaching technology (Weaver II \& Cotrell, 2001), reinforces the idea that school humor can be a relevant indicator of the real classroom success (Ziv, 1988) or at the level of the virtual class (James, 2004).

At the same time, we believe it necessary in such an analysis to follow in essence what is the purpose of using humor in the classroom in relation to what is known as "organizational culture" (Martin, Sullivan, 2013). Certainly, before humor there is the testing stage (McMorris, Boothroyd, \&Pietrangelo, 1997), which aims to see if there is a possibility of its implementation at the level of teaching activity from the perspective of specific taxonomies (Stieger, Formann, Burger, 2011) .

In this context, we mention the idea of specialists in the field, according to which, educational humor can be classified into three categories, namely (Ziegler, 1998): (a) The cognitive humor (which aims to "know information"); (b) The affective humor (how do you make the interpersonal relationships between the actors involved to be positive); (c) The implied humor (which is implied).

Starting from the idea of transforming what education represents, we cannot but bring into question the understanding of humor as an art. But to consider such an idea, we consider it necessary in this context to explain the notion of art. It is understood that we have in mind the phrase "educational art" corroborated with that of "educational humor".

\section{Humor as an art in school}

The starting point in terms of art is the human expressiveness itself. Under 
these conditions, the expository originality, the thematic creativity and the way in which a series of narratives are rendered in literature basically confirm the possibility of humor to exist in the art and through art, or in other words, the humor to exist as an art. As it is to be found in literature and art (Silvestru, 1988), humor reveals a real source of inspiration for children, students, schoolchildren, teachers and, why not, for other people involved in the instructional-educational process.

Beyond such sources of inspiration, we find as a humorous source the intentional (sophistry) or the unintentional (paralogism) use of errors of argument, most often meant to persuade the listener. Such errors are found in lexical creations (Melo, 2014; Possenti, 2010) and in the "reasoning" made "for fun" by some educators. As examples we can give the following stylized expressions that highlight errors and that arouse a smile:

- "The bear is from the pole and the pole shows north. Therefore the bear is from the (north) Pole". - is a humorous error, arising from the consideration of the equivocal term "pole".

- "Students say teachers are naughty"- is a humorous error resulting from the ambiguous nature of the sentence and the failure to comply with a proper intonation; such a humorous error can be interpreted in two variants, namely:

(1) "The students are naughty" = if the intonation is correlated with the commas spoken at the level of assumed discursiveness: "Students, teachers say, are naughty."

(2) "Teachers are naughty" = if the intonation refers to the colon after the verb "says": "students say: teachers are naughty".

Certainly, the errors found at the level of the didactic discursiveness must be "controlled" by the teacher in the communication process. Thus, beyond their discursive existence, the assumption we have in mind highlights the fact that such errors must be brought to the attention of children / pupils precisely in order to be aware, on the one hand, of the relationship between humor and knowledge, and on the other part, of its role and importance in the didactic activity. That is why there are countries that have assimilated in their own school curriculum elements specific to the humorous dimension, even introducing humorous school courses / humorous books or school courses and books about humor. (Bafile, 2003).

A beautiful and useful, efficient and pragmatic lesson is also reflected in the strategy used by the teacher. When we say didactic strategy we have in mind what in the specialized literature is also known as the Rule of the $3 M$ (Methods, Means, Modalities).Our reference is to the idea of play (Suls, 1972), in the dimension of which humor can be framed and applied. Of course, the use of humor in teaching can gain visibility at the level of other ways of intervention / teaching strategies utilized by teachers.

It is in this context that we find it necessary to mention the opinions of some specialists according to which, "when it comes to the small child, the adults around him notice, with predilection, the quantitative, visible acquisitions, those that arouse appreciations, praises or provoke other accumulations, of the same order" (Răileanu, Bujor, Serdenciuc, 2019). In other words, through the game, in 
our opinion, specific coordinates and valences of humor are capitalized in the process of carrying out the didactic activity. After all, following the finalities associated with a didactic activity, a series of information can be deduced regarding the way of development and manifestation of some abilities and skills specific to the child / pupil.

Therefore, play, as a form of early activity, can find its pragmatic values at an older age, precisely because the child's personality develops intensely through it. Even if some authors in the field have shown the role of humor from a psychological viewpoint (Freud, 2002; Ziegler, 2013) or have challenged its use in psychotherapy (Kubie, 1971), we cannot fully agree with such an approach. In this regard, the proof is the specialized literature in the field. So, beyond the educational nature of their use, it should be noted that the use of humor in education (Dinu, 2014), especially at a young age, can be a relevant indicator in initiating, assuming and completing an educational activity.

At the same time, we believe it important that in this context, we specify that the existence of images generally associated with a certain text has allowed the literature (Provine, 1996) to make a series of scientific connections between the amount/blood flow and the intensity of the images viewed by the children (who expressed joy or sadness).The implementation of humor in school (Oldak, 1990) with a humanizing role (Torok, McMorris \& Lin, 2004) reveals the need and relevance of forming children's behavior, of shaping them in the educational process (Călin, Bîrsănescu, 2017). The success of the school activity depends, in fact, on the way in which the idea of humor is implemented, precisely because humor is needed (Botgros, 2016), from the teacher (Forabosco, 1992).

Therefore, precisely in this context, the concept of "humor as art" intervenes, in our opinion, a concept used in the process of didactic communication (Banas, Dunbar, Rodriguez \& Liu, 2011). As a result, the efficiency of a didactic activity related to the applicability of such an idea depends rather on the social and educational implications that it can have later at the level of the instructive-educational activity. More, humor, seen as part of didactic communication (Martin, 2001), basically refers to the assumption of a behavior (White, Lewis, 1990), through which it is necessary to assume a pragmatic strategy at the educational level. Or, the assumption of a conduct already places the educational actors in the ethical dimension of the expression, of the expressiveness and, why not, even of the use / implementation of humor within the didactic activity.

\section{Conclusions}

The examples we have brought in this research approach rather emphasize the important role that the idea of humor plays in the educational dimension. Moreover, the pedagogical valences that we wanted to capture, from our standpoint, involve a certain conditioning between the ethical, pragmatic and artistic nuances.Therefore, our interest was to analyze the image of humor in the literature and how it finds its utility in education / school activity. By summarizing the ideas analyzed in this paper we can draw the following conclusions: 
(1) Our analysis focused on the way in which the idea of humor is perceived and how it can be accepted as an educational and social indicator.This is the reason why such an idea must, in our opinion, find its usefulness in relation to the social and artistic dimension to which it refers. Therefore, our approach also related to the ethical values of the idea of humor.

(2) We believe that the relevance of the main ideas at the level of this investigative approach to be practical and useful for the research itself. Humor as an art in education represents, in fact, making a play upon words, Art in and through humor and in our opinion it must always arouse interest; it should be a subject of reflection at the level of an educational / didactic activity.

(3) We believe that through didactic humor, humor as an art in particular, the optimization of the didactic activity becomes visible within the educational system.That is why we believe that our work can represent a starting point in further research that addresses the issue we dealt with in this paper, namely that of humor as an art.

Therefore, the pragmatism of this research approach highlights a scientific dimension in which the potential effects originating in the results obtained can be a starting point for further research (the extension of the research at regional and national level, the realization and implementation of new projects and educational programs that have as fundamental objective the idea of didactic/educational humor, the humor understood as art).

\section{References}

1. Baid, H.\& Lambert, N.(2010).Enjoyable learning: the role of humour, games, and fun activities in nursing and midwifery education. Nurse Education Today, 548-552

2. Bafile, C. (2003). Comedy in the classroom: just what the doctor ordered? Education World. Retrieved February 11, 2011

3. http://www.educationworld.com/a_issues/chat/chat057.shtm(accesat şi consultat la 22.03 .2020$)$

4. Banas, J.A., Dunbar, N., Rodriguez, D. \& Liu, S.J. (2011). A review of humor in educational settings: Four decades of research.Communication Education, Vol. $1,115-144$

5. Biggs, J., 2003. Teaching for Quality Learning at University, second ed. The Society for Research into Higher Education and Open University Press, Buckingham

6. Cann, A.\& Chantal C. (2014). Sense of humor, stable affect and psychological wellbeing. Europe's Journal of Psychology, 10, 464-479

7. Chauvet, S. \&Hofmeyer, A. (2007), Humor as a facilitative style in problembasedlearning environments for nursing students.Nurse Education Today, Vol. 4, 286-292

8. Cuttance, P. (1994). Monitoring Educational Quality through Performance Indicators for School Practice. School Effectiveness and School Improvement, 5(2), 101-126, DOI: 10.1080/0924345940050201 
9. Dinu, V. (2014). Integrarea umorului în psihoterapie. Revista de psihologie, Bucureşti, ianuarie-martie, 60(1), 89-99

10. Ellias, A. (1973).Humanistic psychotherapy: the rational-emotive approach, New York, Julian Press

11. Florea, M.-M. (2017). Managementul educaţional-comunicarea şcolii cu familia şi societatea.Proceedings Volume: Managementul educational. Legătura dintre scoala, familie si societate (Edited by: Cristian Mihail Rus, Laura Maria Carstea, Antonela Cristina Sofronia, Puiu Petrica Sofronia), Editura Lumen, Iaşi, 139-145

12. Freud, S. (2002). Comicul şi umorul, Editura Trei, Bucureşti

13. Gorham, J. \& Christophel, D. (1990). The relationship of teachers' use of humor in the classroom to immediacy and student learning. Communication Education, 39, 46-62

14. James, D. (2004). A need for humor in online courses. College Teaching, 52 (3), 93-94

15. Jeder, D. (2015). Implications of using humor in the classroom. Procedia Social and Behavioral Sciences. 180:828-833, https://doi.org/10.1016/j.sbspro.2015.02.218

16. Kehr, N., Molstad, S. \& Donahue, R. (1999). Using humor in the college classroom to enhance teaching effectiveness. Dread Courses. College Student Journal, 33(3), 400-407

17. Kubie, L. S. (1971). The destructive potential of humor in psychoterapy.American Journal of Psychiatry, 127 (7), 861-866

18. Margaliot, A., Magid, N. The Role of Creative Thinking in the Process of Forming Teachers' Professional Identity. Creative Education, 2020, 11, 1026-1041 19. Martin, R. A. (2001). Humor, laughter, and physical health: methodological issues and research findings. Psychological bulletin, 127(4), 504

20. McMorris, R. F., Boothroyd, R. A., \& Pietrangelo, D. J. (1997). Humor in educational testing: A review and discussion. Applied Measurement in Education, 10, 269-297

21. Melo, P.da S. (2014). Humour and lexical creation: expressivity in the humoristic smal quartet. Revista do Curso de Letrasda UEPA. Belém. Vol. II. Num. 1.Jan.-Jun

22. Miller, J.R. (1987). The irony of residential schooling. Canadian Journal of Native Education, 3(14)

23. Neiman, A.M. (1993). Rorty, irony education. Studies in Philosophy and Education. 12, june, 205-209

24. Oldak, E. (1990). Comedy for Real Life: A Guide to Helping Kids Survive in an Imperfect World.Publisher: The Comedy Prescription

25. Eşi Posteucă, N.L.(2019). Social and psychological benefits of self-disclosure. International Journal of Social and Educational Innovation (IJSEIro), 6(12), 25-29. 26. Powell, J.P., Andresen, L.W. (1985) Humour and teaching in higher education. Studies Higher Education, 10(1), 7990, DOI: 10.1080/03075078512331378726

27. Provine, R.R. (1996). The study of lughter provides a novel approach to the 
mechanisms and evolution pf vocal production, perception and social behavior. American Scientist, volume 84, 38-45

28. Răileanu, D, Bujor, L., Serdenciuc, N.-L. (2019). Jocuri potrivite pentru profesori inspiraţi şi preşcolari voioşi, Didactica Publishing House

29. Shatz, M.A., LoSchiavo, F.M., 2006. Bringing Life to Online Instruction with Humor http://radicalpedagogy.icaap.org/content/issue8_2/shatz.html (accessed and consulted to 13.04.2020)

30. Silvestru, V. (1998). Umorul în literatură şi arte, Editura Meridiane, Bucureşti

31. Singly, F.Y., Blanchet, A., Gotman, A, Kaufmann, J.-C. (1998). Ancheta şi metodele ei, Editura Polirom, Iaşi, p.21

32. Stamate, D. (2015). Stilurile educative ale familiilor contemporane. Revista de Studii Psihologice, Universitatea Hyperion, Bucureşti, 3, 144-154

33. Stieger, S., Formann, A., Burger, C. (2011). Humor styles and their relationship to explicit and implicit self-esteem. Personality and Individual Differences, 50(5), 747-750

34. Suls, J. M. (1972). A two-stage model for the appreciation of jokes and cartoons: An informationprocessing analysis. The Psychology of Humor: Theoretical Perspectives and Empirical Issues, 1, 81-100

35. Torok, S., McMorris, R. \& Lin, W. (2004). Is humor an appreciated teaching tool? College Teaching, 52 (1), 14-20

36. Yovetich, N.A., Dale A. \& Hudak, M.A. (1990). Benefits of humour in reduction of threat-induced anxiety. Psychological Reports, 66, 51-58

37. Weaver, R. L. II, \& Cotrell, H. W. (2001). Ten specific techniques for developing humor in the classroom. Education, 108, 167-179

38. Weinstein, N., Hodgins, H. S., \& Ostvik-White, E. (2011). Humor as aggression: Effects of motivation on hostility expressed in humor appreciation. Journal of Personality and Social Psychology, 100(6), 1043-1055

39. White, L. A., \& Lewis, D. J. (1990). Humor: a teaching strategy to promote learning. Journal for Nurses in Professional Development, 6(2), 60-64

40. Ziegler, J.(1998). Use of humour in medical teaching. Medical Teacher, Vol.20, No.4, 341-348

41. Zeigler-Hill, V., Besser, A., \& Jett, S. E. (2013). Laughing at the looking glass: Does humor style serve as an interpersonal signal? Evolutionary Psychology, 11(1), 201-226

42. Ziv, A. (1988). Teaching and learning with humor: Experiment and replication, Journal of Experimental Education, 57(1), 5-15 